\section{Simulating Arctic Climate Warmth and Icefield Retreat in the Last Interglaciation}

\author{
Bette L. Otto-Bliesner, ${ }^{1 *}$ Shawn J. Marshall, ${ }^{2}$ Jonathan T. Overpeck, ${ }^{3}$ Gifford H. Miller, ${ }^{4}$ \\ Aixue $\mathrm{Hu},{ }^{1}$ CAPE Last Interglacial Project members
}

In the future, Arctic warming and the melting of polar glaciers will be considerable, but the magnitude of both is uncertain. We used a global climate model, a dynamic ice sheet model, and paleoclimatic data to evaluate Northern Hemisphere high-latitude warming and its impact on Arctic icefields during the Last Interglaciation. Our simulated climate matches paleoclimatic observations of past warming, and the combination of physically based climate and ice-sheet modeling with icecore constraints indicate that the Greenland Ice Sheet and other circum-Arctic ice fields likely contributed 2.2 to 3.4 meters of sea-level rise during the Last Interglaciation.

$\mathrm{D}$ etermining the sensitivity of the Arctic climate system to anomalous forcing and understanding how well climate models can simulate the future state of the Arctic are critical priorities. Over the past 30 years, Arctic surface temperatures have increased $0.5^{\circ} \mathrm{C}$ per decade (1); September Arctic sea ice extent has decreased $7.7 \%$ per decade (2); and the seasonal ablation area for Greenland has increased, on average, by $16 \%$ (3-5). The global climate models being used to estimate future scenarios of Arctic warmth give polar warming of $0.7^{\circ} \mathrm{C}$ to $4.4^{\circ} \mathrm{C}-\mathrm{a}$ large range - as well as a reduction of Arctic sea ice of up to $65 \%$ at the time of the doubling of atmospheric $\mathrm{CO}_{2}$ (6). The Last Interglaciation (LIG, $\sim 130,000$ to 116,000 years ago) is the last time that the Arctic experienced summer temperatures markedly warmer than those in the 20th century and the late Holocene, and it also featured a significantly reduced Greenland Ice Sheet (GIS). Climate models need to be able to reproduce this large, warm climate change in the Arctic if they are to be trusted in their representation of Arctic processes and their predictions for the future.

Paleorecords indicate much warmer Arctic summers during the LIG. Storm beaches and ancient barrier islands with extralimital mollusks of LIG age indicate that the open water north of Alaska was more extensive and lasted seasonally longer (7). Boreal forest communities expanded poleward by as much as 600 to $1000 \mathrm{~km}$ in Russia (8), reaching the coast everywhere except in Alaska (9) and central Canada. Total gas evidence from LIG ice in the Greenland Ice Core Project (GRIP) ice core indicates that the Summit region remained ice-covered, although

${ }^{1}$ Climate and Global Dynamics Division, National Center for Atmospheric Research (NCAR), Boulder, CO 80305, USA. ${ }^{2}$ Department of Geography, University of Calgary, Calgary, Alberta, T2N 1N4, Canada. ${ }^{3}$ Institute for the Study of Planet Earth, Department of Geosciences, and Department of Atmospheric Sciences, University of Arizona, Tucson, AZ 85721, USA. ${ }^{4}$ Institute of Arctic and Alpine Research and Department of Geological Sciences, University of Colorado, Boulder, CO 80309, USA.

*To whom correspondence should be addressed. E-mail: ottobli@ucar.edu possibly up to $\sim 500 \mathrm{~m}$ lower than the ice level at present, at some time in the LIG (10). In contrast, basal ice at Dye-3 (southern Greenland), in the Agassiz, Devon, and Meighen ice caps in the Canadian Arctic, and possibly in Camp Century (northwest Greenland), suggest that these drill sites were ice-free during the LIG $(10,11)$. The increased presence of vegetation over southern Greenland is reconstructed from plant macrofossils (12) and fern spores (13). Elsewhere; pollen, insects, marine plankton, and other proxies document the magnitude of LIG summer warmth across the Arctic (14).

We conducted climate simulations for the LIG with a global, coupled ocean-atmosphereland-sea-ice general circulation model [NCAR Community Climate System Model (CCSM)] (15). We also used ice-sheet simulations with a three-dimensional, coupled ice and heat flow model (16), which spans the entire western Arctic from $57^{\circ} \mathrm{N}$ to $85^{\circ} \mathrm{N}$, including Greenland and smaller scale ice caps in Iceland and the Canadian Arctic (14). We chose to simulate the start of the LIG, approximately 130,000 years ago (130 ka), reflecting evidence of early LIG summer Arctic warmth (14) and of an LIG sealevel high stand of 4 to $6 \mathrm{~m}$ above present day likely by $129 \mathrm{ka} \pm 1000$ years $(17,18)$.

Our climate simulation was forced with the large insolation anomalies of the LIG at $130 \mathrm{ka}$; anomalies driven by changes in Earth's orbit, which are known to have caused warm Northern Hemisphere climate (19-21). The anomalous forcing for the start of the LIG (130 to $127 \mathrm{ka}$ ) was concentrated in the late spring and early summer because of the nature of Milankovitch the GIS is extremely sensitive to warm, earlysummer conditions (22). Positive solar anomalies at the top of the atmosphere exceeded $60 \mathrm{~W} \mathrm{~m}^{-2}$ at high northern latitudes in May to June for 130 ka (Fig. 1) and until 127 ka. After 127 ka, these positive solar anomalies decreased considerably, and by $125 \mathrm{ka}$, they were less than the maximum May-to-June solar anomalies of $\sim 45 \mathrm{~W} \mathrm{~m}^{-2}$ during the Holocene, which were solar anomalies. This timing is important because not enough to melt the GIS much beyond its modern configuration. Annual mean changes of insolation at high northern latitudes for $130 \mathrm{ka}$ were much smaller, less than $6 \mathrm{~W} \mathrm{~m}^{-2}$; global annual mean forcing was very small, $0.2 \mathrm{~W} \mathrm{~m}^{-2}$.

A comparison between proxy-based reconstructions for the Arctic LIG and those simulated with the CCSM climate model shows good agreement (Fig. 2). Solar anomalies drive significant simulated summer (June, July, and August) warming in the Arctic (for $60^{\circ} \mathrm{N}$ to $90^{\circ} \mathrm{N}$, an average warming of $2.4^{\circ} \mathrm{C}$ with significant regional variation) (Fig. 2). In agreement with paleoclimatic observations, simulated warming in excess of $4^{\circ} \mathrm{C}$ occurs in the northern Hudson BayBaffin Island-Labrador Sea region, and across to the seas adjacent to northern and eastern Greenland. Greenland warms by $3^{\circ} \mathrm{C}$ or greater along the edges of the ice cap and by $2.8^{\circ} \mathrm{C}$ in central Greenland in CCSM, somewhat less than observed. Less summer warming is indicated for northern Europe $\left(2^{\circ} \mathrm{C}\right.$ to $\left.3^{\circ} \mathrm{C}\right)$, as well as Alaska and western Canada $\left(0^{\circ} \mathrm{C}\right.$ to $\left.2^{\circ} \mathrm{C}\right)$, in both the proxy reconstruction and CCSM. The simulated warming over Siberia is $2^{\circ} \mathrm{C}$ to $4^{\circ} \mathrm{C}$, somewhat less than the paleodata in parts of this region.

The insolation anomalies result in increased sea ice melting early in the summer season, with reduced sea ice extending from April into November. The minimum LIG Arctic sea-ice area simulated in August and September is 50\% less than that simulated for present day, with $50 \%$ summer coverage in the Arctic Ocean only occurring poleward of $80^{\circ} \mathrm{N}$ (fig. S1). The reduction of summer sea ice leads to simulated warming of the Arctic Ocean north of Alaska by $\sim 2^{\circ} \mathrm{C}$. The North Atlantic warms by $1^{\circ} \mathrm{C}$ to $2^{\circ} \mathrm{C}$, with above-freezing temperatures extending northward along circumcoastal regions, and substantial warming extending as far east as Severnaya Zemlya in CCSM. The CCSM is in accord with marine records that indicate modest warming $\left(0^{\circ} \mathrm{C}\right.$ to $\left.4^{\circ} \mathrm{C}\right)$ at LIG (Fig. 2).

The simulated temperature response of the Arctic to altered LIG insolation is significant over the ice sheet and the surrounding waters of Greenland. Feedbacks associated with reduced sea ice and a warmer North Atlantic Ocean and Labrador Sea act to warm all of Greenland during the summer months, with the southern quarter and far northern coastal regions averaging above freezing for multiple months. Maximum daily surface temperatures during the summer are above freezing over the entire ice sheet. Annual snow depths decrease significantly along the southern, western, and northern edges of the ice sheet (17). These decreases are primarily due to melting with warmer surface temperatures. Modeled precipitation rates are generally not significantly different from present, except for marginally significant increases in northwest and central Greenland and southeast Iceland, associated with warmer nearby oceans.

Simulated margins of the GIS, as well as smaller Arctic icefields, respond immediately to 


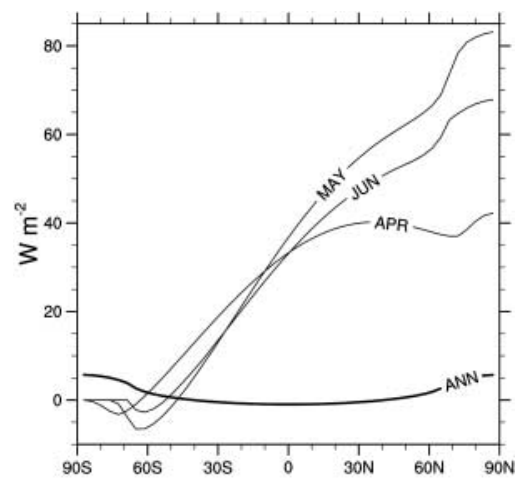

Fig. 1. Anomalies of solar radiation incoming at the top of the atmosphere at 130 ka relative to present as a function of latitude. Large positive anomalies occur over the Arctic during boreal late spring and early summer. Northern high-latitude annual mean anomalies are small and positive, whereas global annual mean anomalies are close to zero. Similar high-latitude anomalies occur for boreal late spring and early summer through 127 $\mathrm{ka}$, diminishing considerably after that time. Jun, June; Apr, April; Ann, annual.

the warmer spring and summer temperatures The total icefield ablation area increases from $2.64 \times 10^{5} \mathrm{~km}^{2}$ for modern time to $5.25 \times 10^{5}$ $\mathrm{km}^{2}$ in the LIG, with melt rates near the ice margins increasing by as much as $1 \mathrm{~m} /$ year. Greater snow accumulation compensates for elevated melt rates in southeast Iceland, central Greenland, and isolated coastal sites in Greenland, giving small, positive mass-balance perturbations for the LIG of $\sim 0.2 \mathrm{~m} /$ year. Elsewhere in the western Arctic, increased melt rates and an extended ablation season lead to negative mass-balance perturbations, with initial losses of -0.3 to $-0.6 \mathrm{~m} /$ year in most of coastal Greenland. On average over the western Arctic, the mass-balance perturbation is $-0.19 \mathrm{~m} /$ year.

As the simulated ice caps retreat over several millennia in response to the orbitally induced warming, loss of ice mass leads to surface lowering, an amplification of the mass-balance perturbation, and accelerated retreat. The sustained negative mass-balance perturbations cause the almost-complete demise of icefields in the Queen Elizabeth Islands, consistent with the ice-core inferences discussed in Koerner $(11,23)$. In approximately 2000 years, the GIS has retreated such that Dye-3 becomes ice-free, in agreement with LIG paleorecords (Fig. 3A) (11-13). In this configuration, Greenland and the western Arctic icefields contribute $2.2 \mathrm{~m}$ of sea-level rise; this is the minimum sea-level rise that the Arctic likely contributed during the LIG. After an additional millennium, the simulated LIG surface drawdown at the paleodivide is $\sim 570 \mathrm{~m}$, near the constraint provided by ice-core data (10). This minimal GIS configuration (Fig. 3B) yields a maximum Arctic sea-level contribution of $3.4 \mathrm{~m}$.

Our simulated GIS is not in equilibrium, and continued warmth would drive a smaller and
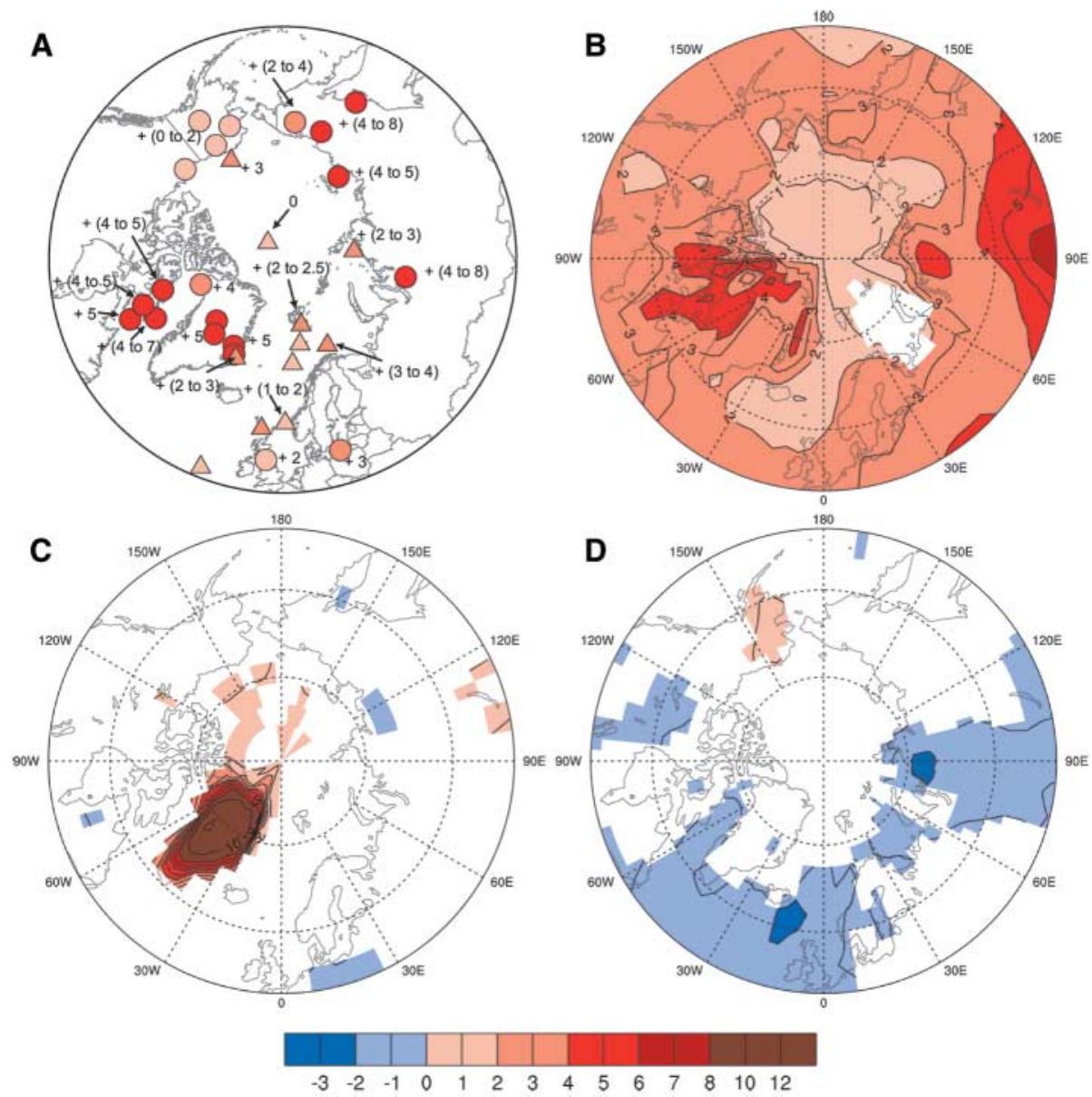

Fig. 2. Arctic summer surface-temperature anomalies. (A) Maximum observed LIG summer temperature anomalies relative to present derived from quantitative [terrestrial (circles) and marine (triangles)] paleotemperature proxies as part of CAPE Last Interglacial Project (14). (B) LIG summer (June, July, and August) temperature anomalies relative to present simulated by CCSM for $130 \mathrm{ka}$. (C) Additional LIG summer warming for our no-Greenland Ice Sheet sensitivity simulation relative to our LIG simulation with the GIS. (D) Summer temperature anomalies for a freshwater anomaly of 0.1 sverdrup to the North Atlantic for 100 years simulated by CCSM. For the CCSM simulations, only anomalies significantly different from natural model variability at $95 \%$ confidence interval are shown.

lower ice sheet and continued sea-level rise. However, the GIS configurations in Fig. 3 are consistent, in terms of height and area, with observed ice-core data, thus providing a constraint on the Canadian Arctic and Iceland icefields and of the GIS at their smallest size during the LIG (Fig. 3). Moreover, our use of observations and model together indicate that the minimal LIG GIS was a steeply sided ice sheet in central and northern Greenland (Fig. 3) and that this ice sheet, combined with the change in other Arctic ice fields, likely generated 2.2 to 3.4 $\mathrm{m}$ of early LIG sea-level rise (1.9 to $3.0 \mathrm{~m}$ from Greenland and 0.3 to $0.4 \mathrm{~m}$ from Arctic Canada and Iceland). Previous modeling studies of the LIG, based on independent, ice-core-derived temperature histories $(24,25)$ from GRIP (Greenland) $\delta^{18} \mathrm{O}$ and Vostok (Antarctica) $\delta \mathrm{D}$ data, also suggest a minimum GIS within a few millennia of the maximum LIG insolation anomaly.

Our climate model captures the terrestrial warming within the uncertainties of proxy esti- mates, except over Siberia. In Siberia, the model underestimates the observed warming by up to $1^{\circ} \mathrm{C}$ to $2^{\circ} \mathrm{C}$. Previous modeling studies have shown that Arctic vegetation changes act as a positive feedback for past periods of enhanced summer solar radiation, including the Holocene $(26,27)$ and the LIG (28). Our simulation lacked this positive feedback, just as this feedback is missing in most projections of future warming. However, our results indicate that CCSM does a good job of simulating much of the observed Arctic response to altered radiative forcing without this feedback, confirming that the size of the missing vegetation feedback is likely smaller than was previously estimated $(14,19,27)$.

A sensitivity simulation with CCSM with all ice removed from Greenland and replaced with lower-albedo bedrock gives a measure of the large positive feedbacks associated with the large reduction of surface albedos due to ice sheet retreat and vegetation growth over Greenland (Fig. 2C). The additional warming is primarily a 
Ice thickness (m)

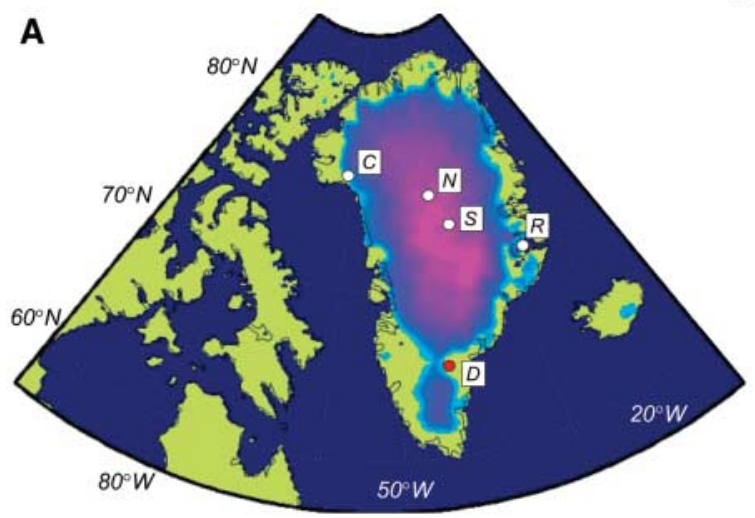

Fig. 3. Simulated ice-sheet thickness maps for LIG climate forcing. (A) Configuration for when the location of Dye-3 ice core becomes ice-free. This configuration gives the minimum sea-level rise $(2.2 \mathrm{~m})$ that the Arctic likely contributed during the LIG. (B) Configuration for a paleodivide elevation of $570 \mathrm{~m}$ lower than present. This configuration gives the maximum Arctic sea-level rise $(3.4 \mathrm{~m})$ that the Arctic likely contributed during the LIG.
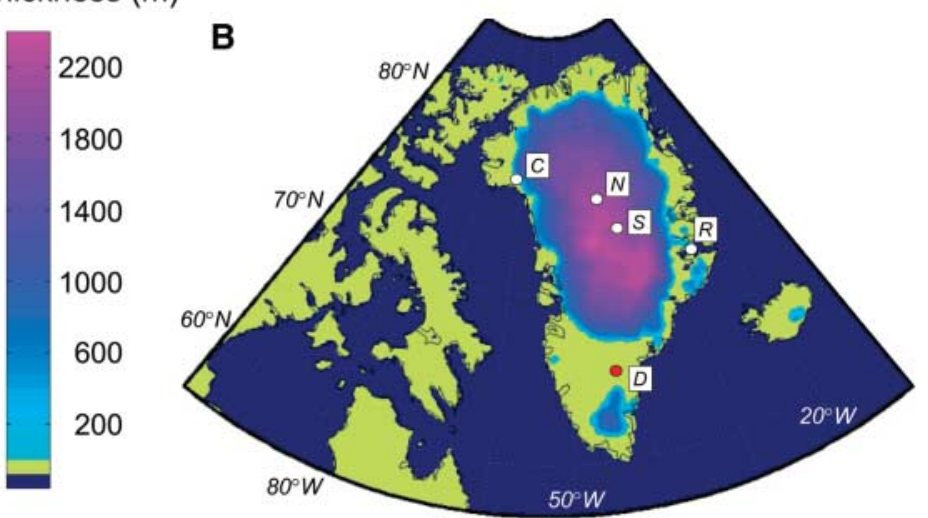

Greenland ice-core observations indicate early LIG ice (white circles) at Renland (marked $\mathrm{R} ; 71.3^{\circ} \mathrm{N}, 26.7^{\circ} \mathrm{W}$ ), North Greenland Ice Core Project (NGRIP) (marked N; $75.1^{\circ} \mathrm{N}, 42.3^{\circ} \mathrm{W}$ ), Summit [GRIP and Greenland Ice Sheet Project 2 (GISP2)] (marked S; $72.5^{\circ} \mathrm{N}, 37.3^{\circ} \mathrm{W}$ ), and possibly Camp Century (marked $\mathrm{C} ; 77.2^{\circ} \mathrm{N}, 61.1^{\circ} \mathrm{W}$ ), but not (red circle) at the Dye-3 ice core site (marked $\mathrm{D} ; 65.2^{\circ} \mathrm{N}, 43.8^{\circ} \mathrm{W}$ ). local response over Greenland. Surface temperatures warm an additional $7^{\circ} \mathrm{C}$ at Renland and Dye- 3 and more than $10^{\circ} \mathrm{C}$ at GRIP. This warming is clearly an overestimate compared with ice-core and other proxy estimates (Fig. 2), confirming the likelihood that the GIS retreated only to the smaller and steeper configuration that we simulated (Fig. 3).

A sea-level rise of $3.4 \mathrm{~m}$ over 3000 years is equivalent to freshwater forcing of the North Atlantic and Labrador Sea of 0.013 sverdrup. It is reasonable to assume, however, that the rate of meltwater discharge would not have been constant in time, and could have been greater at some times than others during the drawdown of the GIS. We thus performed a sensitivity simulation with 0.1 sverdrup of water inserted into the present-day North Atlantic over 100 years. This freshwater forcing yields a simulated $25 \%$ slowdown of the North Atlantic thermohaline circulation and annual cooling of $1.5^{\circ} \mathrm{C}$ south of Greenland, within the range of sensitivities of 12 climate model simulations of $-3.9^{\circ} \mathrm{C}$ to $+0.7^{\circ} \mathrm{C}(29)$. Simulated summer cooling is generally $1{ }^{\circ} \mathrm{C}$ to $2^{\circ} \mathrm{C}$ over much of the North Atlantic and Labrador Sea (Fig. 2D). Even with this more extreme freshwater forcing than is implied by our simulated average LIG meltwater rate, summer surface temperature anomalies over Greenland remain positive, which is an indication of the implied primacy of the large orbital forcing anomalies. These results therefore indicate that the likely impact on the North Atlantic of any Greenland meltwater would not have inhibited the meltback of Greenland.

Our results confirm that the NCAR climate model (with doubled atmospheric carbon dioxide equilibrium sensitivity of $2.2^{\circ} \mathrm{C}$ ) captures key aspects of Arctic sensitivity to anomalous LIG forcing. Simulated summer Arctic warming is up to $5^{\circ} \mathrm{C}$ (as compared with a simulated global cooling of $0.7^{\circ} \mathrm{C}$ and Northern Hemi- sphere warming of $1.3^{\circ} \mathrm{C}$ ), and simulated sea-ice retreats by $50 \%$. The climate model anomalies drive large-scale ice-sheet retreat in the Western Arctic that is consistent with available ice-core records. Within a few millennia, most of the icefields in Arctic Canada and Iceland melted away, and the GIS was reduced to a steep ice dome in central and northern Greenland. We cannot comment on exactly when this ice configuration could have occurred during the LIG; there are no paleoclimatic observational constraints on the time evolution of ice-sheet retreat, and the lack of meltwater-driven, icedynamical processes in current ice-sheet models (30) prevents an evaluation of ice-sheet model sensitivity. However, our results give a likely Arctic (including Greenland) contribution to LIG sea-level rise above modern day of no more than $3.4 \mathrm{~m}$. Despite the different mechanisms of warming, these results indicate that the impact on Arctic environments over the next century can be expected to be substantial if predicted future climate change comes to pass (17).

\section{References and Notes}

1. J. C. Comiso, J. Clim. 16, 3498 (2003)

2. J. C. Stroeve et al., Geophys. Res. Lett. 32, L04501 (2005).

3. W. Abdalati, K. Steffen, J. Geophys. Res. 106, 33983 (2001).

4. W. Krabill et al., Science 289, 428 (2000).

5. W. S. B. Paterson, N. Reeh, Nature 414, 60 (2001).

6. G. M. Flato et al., Clim. Dyn. 23, 229 (2004).

7. J. Brigham-Grette, D. M. Hopkins, Quaternary Res. 43, 154 (1995)

8. A. V. Lozhkin, P. M. Anderson, Quaternary Res. 43, 147 (1995).

9. M. E. Edwards, T. D. Hamilton, S. A. Elias, N. H. Bigelow, A. P. Krumhardt, Arctic Antarctic Alpine Res. 35, 460 (2003).

10. D. Raynaud, J. A. Chappellaz, C. Ritz, P. Matinerie, J. Geophys. Res. 102, 26607 (1997).

11. R. M. Koerner, Science 244, 964 (1989).

12. O. Bennike, J. Böcher, Boreas 23, 479 (1994).

13. C. Hillaire-Marcel, A. De Vernal, G. Bilodeau, A. ]. Weaver, Nature 410, 1073 (2001)

14. Materials and methods are available as supporting material on Science Online.
15. J. T. Kiehl, P. R. Gent, J. Clim. 17, 3666 (2004).

16. S. J. Marshall, K. M. Cuffey, Earth Planet. Sci. Lett. 179, 73 (2000).

17. J. T. Overpeck et al., Science 311, 1747 (2006).

18. M. T. McCulloch, T. Esat, Chem. Geol. 169, 107 (2000).

19. M. Montoya, H. von Storch, T. J. Crowley, J. Clim. 13, 1057 (2000).

20. J. E. Kutzbach, R. G. Gallimore, P. ]. Guetter, Quaternary Int. 10-12, 223 (1991).

21. T. J. Crowley, K.-Y. Kim, Science 265, 1566 (1994).

22. W. Krabill et al., Geophys. Res. Lett. 31, L24402 (2004).

23. R. M. Koerner, D. A. Fisher, Ann. Glaciology 35, 19 (2002).

24. K. M. Cuffey, S. J. Marshall, Nature 404, 591 (2000).

25. L. Tarasov, W. R. Peltier, J. Geophys. Res. 108, 2143 (2003).

26. J. A. Foley, ]. E. Kutzbach, M. T. Coe, S. Levis, Nature 371, 52 (1994).

27. M. Kerwin et al., Paleoceanography 14, 200 (1999).

28. S. P. Harrison, ]. E. Kutzbach, I. C. Prentice, P. J. Behling, M. T. Sykes, Quaternary Res. 43, 174 (1995).

29. R. J. Stouffer et al., J. Clim., in press.

30. R. B. Alley, P. U. Clark, P. Huybrechts, I. Joughin, Science 310, 456 (2005).

31. Circum-Arctic PaleoEnvironments (CAPE) is a program within the International Geosphere-Biosphere Program (IGBP)-Past Global Changes (PAGES); the CAPE-LIG compilation was supported by the NSF-Office of Polar ProgramsArctic System Science (PARCS) and PAGES. The CAPE Last Interglacial Project Members are P. Anderson, O. Bennike, N. Bigelow, ]. Brigham-Grette, M. Duvall, M. Edwards, B. Fréchette, S. Funder, S. Johnsen, J. Knies, R. Koerner, A. Lozhkin, G. MacDonald, S. Marshall, J. Matthiessen, G. Miller, M. Montoya, D. Muhs, B. Otto-Bliesner, J. Overpeck, N. Reeh, H. P. Sejrup, C. Turner, and A. Velichko. We thank E. Brady and D. Schimel for helpful discussions; R. Tomas and M. Stevens for figures; and C. Shields for design and running of the simulations. We acknowledge the efforts of a large group of scientists at the NCAR, at several Department of Energy and National Oceanic and Atmospheric Administration labs, and at universities across the United States who contributed to the development of CCSM2. Computing was done at NCAR as part of the Climate Simulation Laboratory. Funding for NCAR and this research was provided by NSF.

\section{Supporting Online Material}

www.sciencemag.org/cgi/content/full/311/5768/1751/DC1

Materials and Methods

Figs. S1 to S4

References

30 September 2005; accepted 1 March 2006 10.1126/science. 1120808 